\title{
Вплив психофізіологічних та морфофункціональних показників спортсменів високої кваліфікації на результат пропливання дистанції 400 метрів вільним стилем
}

\section{Ольга Пилипко Аліна Пилипко}

Харківська державна академія фізичної культури, Харків, Україна

Мета: визначити вплив психофізіологічних та морфофункціональних показників спортсменів високої кваліфікації на результат пропливання ними дистанції 400 метрів вільним стилем.

Матеріал і методи: аналіз та узагальнення літературних джерел, антропометричні та фізіологічні вимірювання, тестування психофізіологічних показників, методи математичної статистики. Обстежувана група складалася з учасників фінальних запливів Чемпіонатів та Кубків України з плавання на дистанції 400 метрів вільним стилем, які мали рівень спортивної кваліфікації МСу.

Результати: авторами охарактеризовані психофізіологічні та морфофункціональні показники висококваліфікованих спортсменів, які спеціалізуються в плаванні вільним стилем на дистанції 400 метрів, визначений ступінь їхнього впливу на результат подолання змагальної дистанції 400 метрів.

Висновки: показники морфофункціонального розвитку плавців є більш значущими для досягнення високих результатів на дистанції 400 метрів вільним стилем, аніж психофізіологічні параметри; побудова тренувального процесу висококваліфікованих спортсменів різної дистанційної спеціалізації має здійснюватись з урахуванням ступеню впливу морфофункціональних та психофізіологічних показників структури спеціальної підготовленості на змагальний результат.

Ключові слова: висококваліфіковані плавці, вільний стиль, 400 метрів, психофізіологічні та морфофункціональні показники, вплив.

\section{Вступ}

Постійний ріст результатів, стрімко зростаюча конкуренція у сучасному спортивному плаванні диктує необхідність пошуку найбільш перспективних шляхів оптимізації тренувальної та змагальної діяльності [3; 9; 14; 17].

Комплексний аналіз показників структури спеціальної підготовленості спортсменів дозволяє визначити найбільш значущі за своїм впливом на результат параметри. Урахування їх при побудові тренувального процесу дозволить вдосконалити підготовку спортсменів високої кваліфікації, що, в свою чергу, призведе до покращення спортивних результатів.

На даний час фахівцями у галузі спортивного плавання достатньо повно розглянуті показники технікотактичної майстерності, антропометричного розвитку, функціональної підготовленості кваліфікованих плавців, які є значущими на дистанціях різної довжини $[1 ; 6 ; 7$; $8 ; 10 ; 13 ; 15 ; 16]$. Однак, вивчення психофізіологічних параметрів залишається відносно осторонь, а морфофункціональні характеристики спортсменів потребуюсь безперервного оновлення $[2 ; 4 ; 5 ; 11 ; 12]$.

Проведення досліджень в даному напрямку дозволить відкрити нові перспективи у вирішенні проблеми вдосконалення тренувальної діяльності з урахуванням дистанційної спеціалізації висококваліфікованих спортсменів-плавців.
Мета роботи: визначити вплив психофізіологічних та морфофункціональних показників висококваліфікованих спортсменів на результат пропливання дистанції 400 метрів вільним стилем.

\section{Завдання дослідження:}

1. Дослідити особливості морфофункціонального розвитку спортсменів високої кваліфікації, які спеціалізуються в плаванні вільним стилем на дистанції 400 метрів.

2. Охарактеризувати психофізіологічні параметри висококваліфікованих плавців, що успішно долають змагальну дистанцію 400 метрів вільним стилем.

3. Визначити ступінь кореляційного зв'язку між психофізіологічними та морфофункціональними показниками спортсменів високої кваліфікації та результатом подолання ними дистанції 400 метрів.

\section{Матеріал і методи дослідження}

Для вирішення поставлених завдань у роботі були використані наступні методи: аналіз та узагальнення літературних джерел, антропометричні та фізіологічні вимірювання, тестування психофізіологічних показників, методи математичної статистики.

Збір експериментальних даних здійснювався на Чемпіонатах і Кубках України з плавання. Обстежувана група у кількості 12 чоловік складалася з учасників фінальних запливів на дистанції 400 метрів вільним сти- 


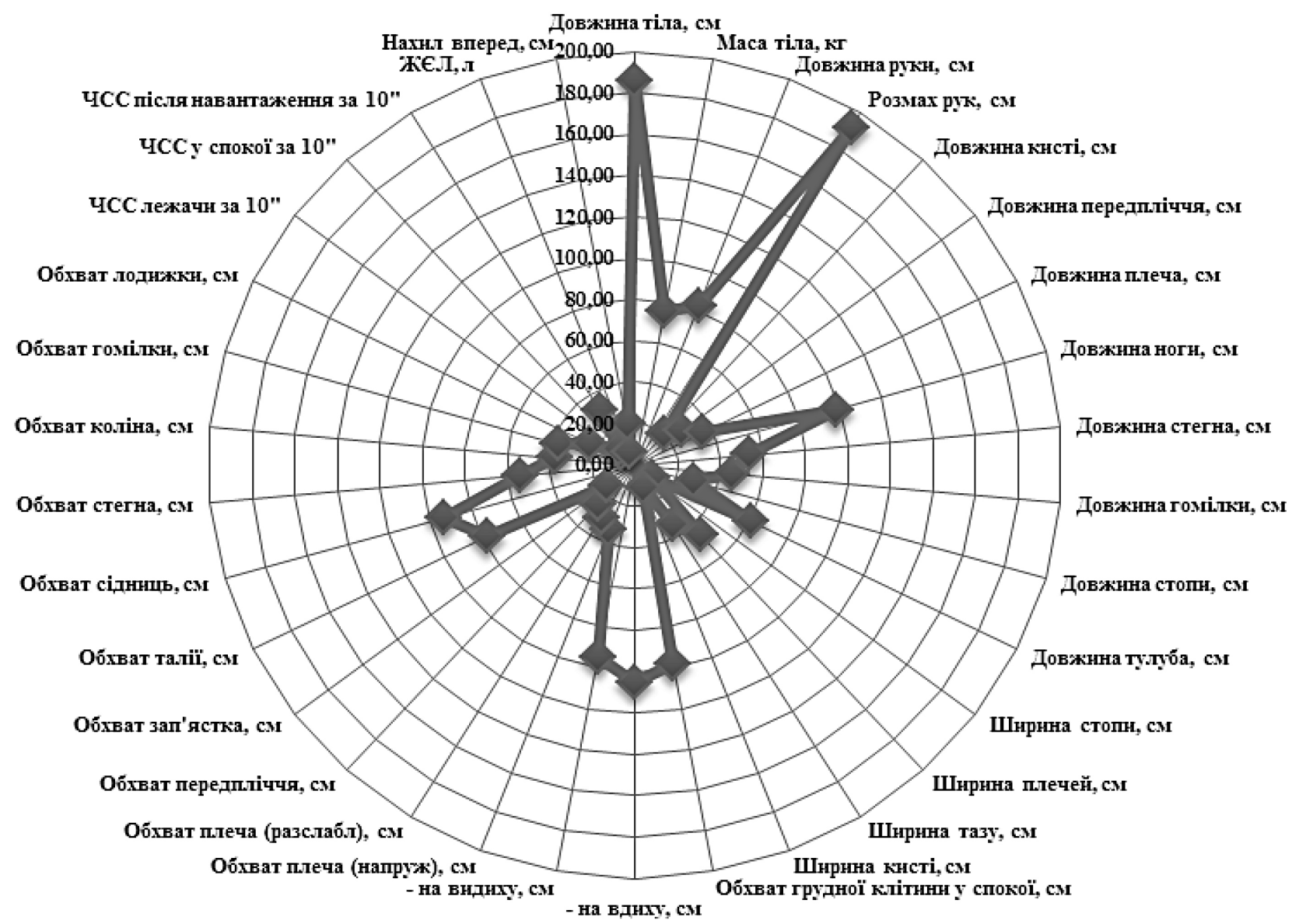

Рис. 1.

Морфофункціональний профіль висококваліфікованих спортсменів, які спеціалізуються в плаванні вільним стилем на дистанції 400 метрів

лем. Всі спортсмени, які приймали участь у експерименті, були членами збірної команди України з плавання і мали рівень кваліфікації МСУ.

\section{Результати дослідження}

Результат в плаванні визначається багатьма факторами, серед яких важливе місце відводиться морфофункціональним та психофізіологічним параметрам.

Особливості морфофункціонального розвитку плавців-стайєрів оцінювались нами на основі вимірювання повздовжніх, поперечних та обхоплювальних розмірів тіла та показників функціонального розвитку. Загалом було розглянуто 34 параметри.

На основі отриманого цифрового матеріалу з'явилась можливість побудувати морфофункціональний профіль спортсменів, які спеціалізуються на дистанції 400 метрів вільним стилем (рис. 1).

Плавці даної спеціалізації мають середні значення довжини (185,58 \pm 7,69 см) та маси тіла $(75,42 \pm 5,92$ кг), обхоплювальних розмірів грудної клітини (у спокої: 98, $17 \pm 4,28$ см, на вдиху: 104,95 $\pm 5,49$ см, на видиху: 95,00 $\pm 4,73$ см). Вони мають довгі кінцівки і їхні сегменти, міцну статуру, нормостенічний тип конституції.

У цих спортсменів відмічаються гарні показники гнучкості, про що свідчать результати тесту «нахил вперед» $(20,07 \pm 5,04 \mathrm{~cm})$.

Параметр ЖєЛ, який є одним з основних показників стану системи зовнішнього дихання, знаходиться на рівні значень 6,89 \pm 1,49 л.

Відмічені особливості пояснюються виконанням роботи переважно у зоні аеробного енергозабезпечення, яка пред'являє високі вимоги до функціональних можливостей плавців та до їхнього морфотипу.

Відсутність у стайєрів великих охоплювальних розмірів, у порівнянні з спринтерами, пов'язана з підвищенням вимог до їх гідродинамічних якостей - рівноваги тіла у воді, обтічності, плавучості.

Оцінка психофізіологічних особливостей плавців високої кваліфікації, що спеціалізуються на дистанції 400 метрів вільним стилем, проводилася за показниками: часу рухової реакції на звуковий подразник; почуття часу, концентрації уваги; частоти рухів за заданий проміжок часу; визначення екстравертованості та інтровертованості особистості.

Середні значення досліджуваних параметрів, зафіксовані у спортсменів в тестах, представлені у таблиці 1 .

Як видно з таблиці 1, результати, які характеризують швидкість реагування на звуковий подразник, 
Таблиця 1

Психофізіологічні показники висококваліфікованих спортсменів, які спеціалізуються в плаванні вільним стилем на дистанції 400 метрів (n = 12)

\begin{tabular}{|c|c|c|c|c|c|c|c|}
\hline \multirow[b]{3}{*}{$\begin{array}{c}\text { № } \\
\text { 3/II }\end{array}$} & \multirow[b]{3}{*}{ ПІБ } & \multicolumn{6}{|c|}{ Результати тестів } \\
\hline & & \multirow{2}{*}{ 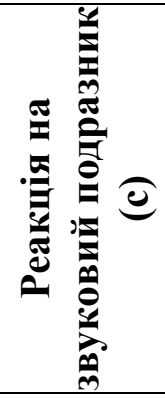 } & \multirow{2}{*}{ 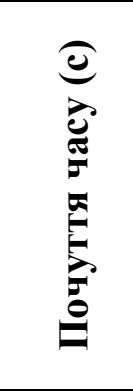 } & \multirow[b]{2}{*}{ 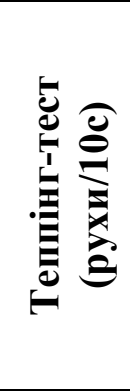 } & \multicolumn{2}{|c|}{$\begin{array}{c}\text { Опитувальник } \\
\text { Айзенка }\end{array}$} & \multirow{2}{*}{ 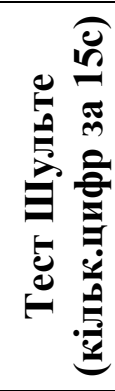 } \\
\hline & & & & & 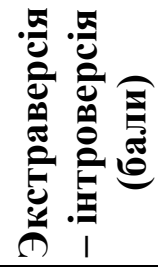 & 承 & \\
\hline 1. & Ш-ц К. & 0,149 & 28,744 & 65,50 & 15 & 6 & 11 \\
\hline 2. & Р-к M. & 0,168 & 24,5 & 56,83 & 15 & 5 & 16 \\
\hline 3. & Ш-в М. & 0,129 & 25,6 & 63,00 & 17 & 12 & 11 \\
\hline 4. & М-й П. & 0,151 & 28,59 & 61,33 & 18 & 14 & 11 \\
\hline 5. & C-й O. & 0,133 & 24,5 & 57,83 & 18 & 7 & 15 \\
\hline 6. & В-ко В. & 0,182 & 29,94 & 37 & 15 & 10 & 14 \\
\hline 7. & $\Gamma$-в А. & 0,163 & 23,42 & 34,33 & 15 & 16 & 13 \\
\hline 8. & Т-ко I. & 0,174 & 30,84 & 42 & 19 & 11 & 14 \\
\hline 9. & Д-ко Я. & 0,198 & 31 & 39 & 19 & 12 & 12 \\
\hline 10. & Д-в Д. & 0,174 & 40 & 38,5 & 16 & 13 & 14 \\
\hline 11. & К-ко М. & 0,155 & 31,84 & 38 & 19 & 17 & 15 \\
\hline 12. & К-й К. & 0,147 & 34,2 & 50,33 & 10 & 11 & 13 \\
\hline \multicolumn{2}{|c|}{ Середні значення } & 0,16 & 29,43 & 48,64 & 16,33 & 11,17 & 13,25 \\
\hline \multicolumn{2}{|c|}{ Стандартне відхилення } & 0,02 & 4,72 & 11,67 & 2,61 & 3,74 & 1,71 \\
\hline
\end{tabular}

в середньому знаходяться в досліджуваній групі на рівні значень 0,16 \pm 0,02 с, при цьому переважна кількість спортсменів демонструвала відносно стабільні значення у кожній із 10 спроб.

50 \% з числа досліджуваних плавців мають добре розвинуте почуття часу, 33,3 \% демонструють різницю з відчуттям реального часу в менший бік, в свою чергу 16,7 \% мають уповільнене відчуття часового проміжку.

Отримані результати тесту Шульте свідчать про те, що у спортсменів даної спеціалізації наявна як середня, так і висока ступінь концентрації уваги, адже у відведений проміжок часу плавці знаходили відносно велику кількість цифр. Середні значення у групі склали 13,25 \pm 1,71 цифр/15 с.

При виконанні теппінг-тесту найбільш результативною у обстежених плавців була перша спроба (рис. 2).

Після стрімкого погіршення показників у другій та третій спробах наставала відносна стабілізація з подальшим покращенням результатів у заключній спробі.

Результати тестування за опитувальником Айзенка дозволили виявити, що практично усі спортсмени обстежуваної групи мають екстравертований тип особистості.

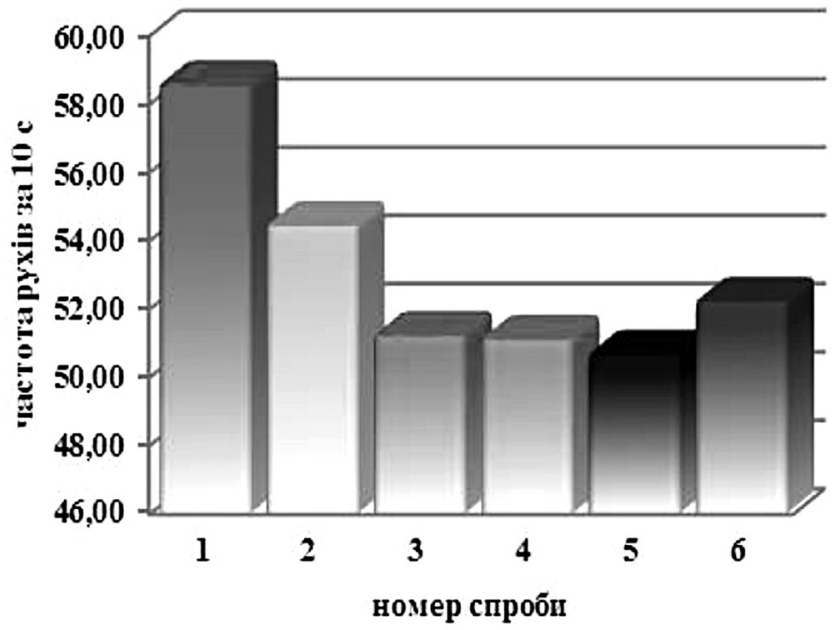

Рис. 2.

Результати виконання теппінг-тесту висококваліфікованими спортсменами, які спеціалізуються в плаванні на дистанції 400 метрів вільним стилем 


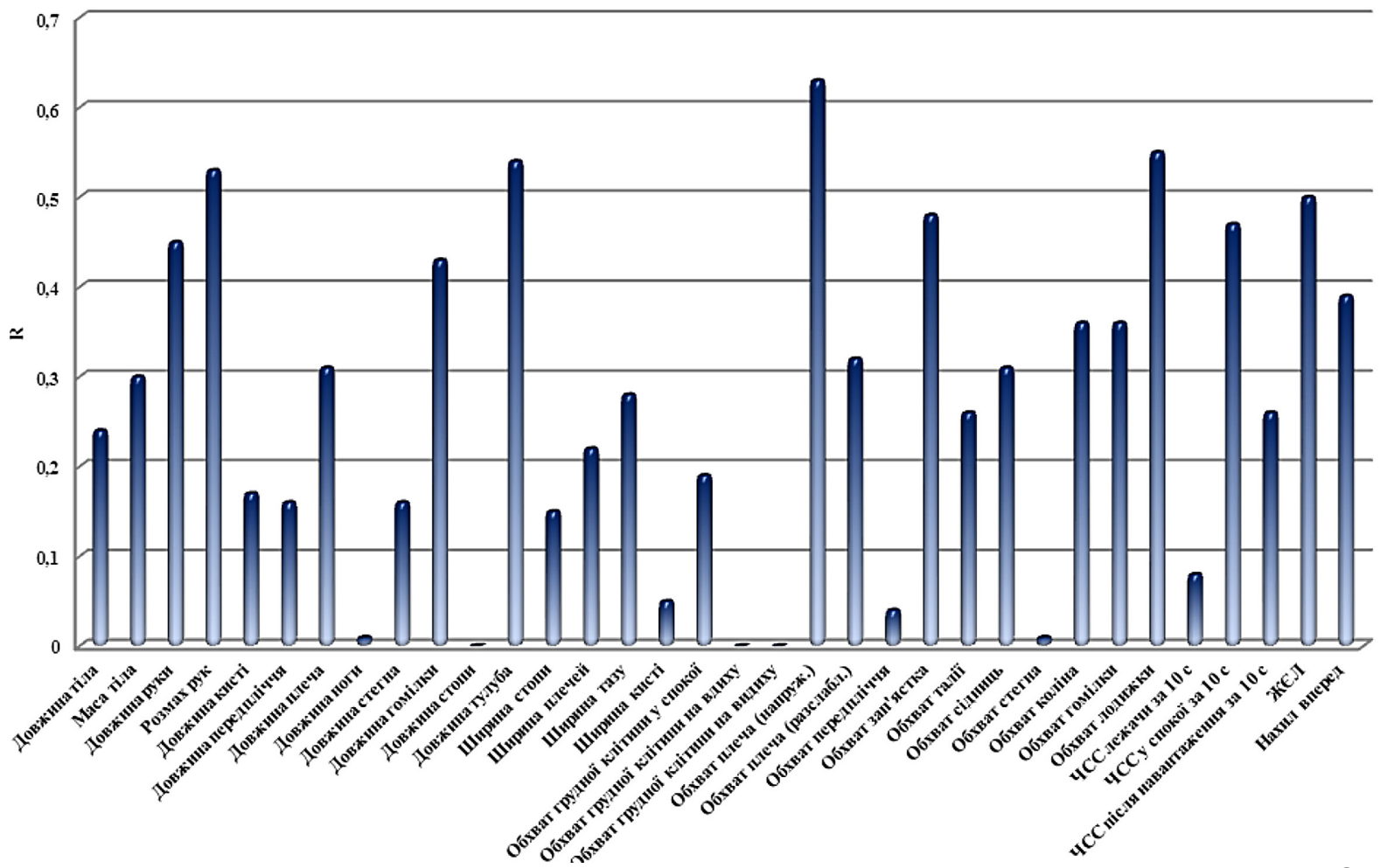

Рис. 3.

Ступінь кореляційного взаємозв'язку між морфо-функціональними показниками плавців високої кваліфікації та спортивним результатом на дистанції 400 метрів вільним стилем

В свою чергу визначення за шкалою «емоційна стійкість - нейротизм» виявило у 83,3 \% плавців переважаючі риси емоційної стійкості. Тільки два спортсмени, а саме К-ко М. та Г-в А., мають показники на рівні 17 та 16 балів відповідно, що свідчить про виражений нейротизм.

Проведений аналіз ступеню кореляційного взаємозв'язку між показниками морфофункціонального розвитку та спортивним результатом на дистанції 400 метрів вільним стилем дозволив дійти до висновку, що найбільш важливими для демонстрації високих спортивних результатів є показники розмаху рук, довжини тулуба, обхватних розмірів плеча в напруженому стані, обхвату лодижки та жєЛ (R дорівнює -0,53, -0,54, -0,63, -0,55, -0,50 відповідно) (рис. 3).

Значущими $€$ також показники довжини руки $(\mathrm{R}=$ $-0,45)$ та гомілки $(R=-0,43)$, обхват зап'ястка $(R=-0,48)$ та чСС у спокої $(R=0,47)$.

Отже, результат подолання дистанції 400 мерів вільним стилем в більшій мірі визначається параметрами обхоплювальних розмірів кінцівок та довжиною рук, що забезпечує великий «крок» циклу гребкових рухів, а також високими показниками функціонального розвитку.

В свою чергу психофізіологічні показники спортсменів несуттєво впливають на результат подолання ними дистанції 400 метрів (рис. 4).

Значущий впив зафіксований лише у параметра «реакція на звуковий подразник» $(R=-0,50)$.

Плавці-стайєри повинні мати сильний тип нервової системи, що в свою чергу є необхідною умовою для ефективного перенесення довготривалих монотонних навантажень.
Виявлені взаємозв'язки необхідно враховувати при побудові тренувального процесу спортсменів даної дистанційної спеціалізації, що буде впливати на досягнення високих спортивних результатів.

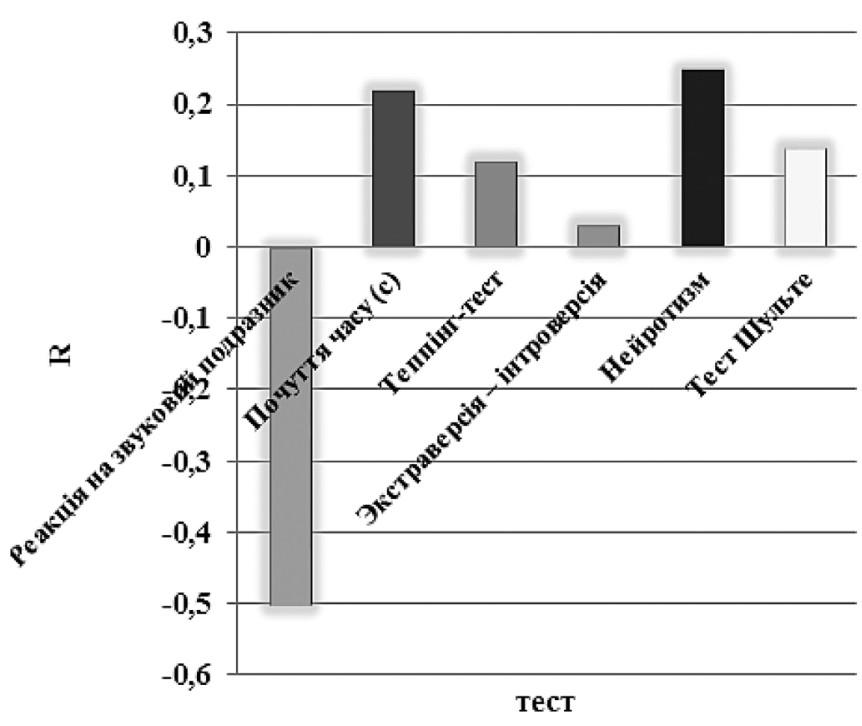

Рис. 4.

Ступінь кореляційного взаємозв'язку між психофізіологічними показниками висококваліфікованих плавців та спортивним результатом на дистанції 400 метрів вільним стилем 


\section{СЛОБОЖАНСЬКИЙ НАУКОВО-СПОРТИВНИЙ ВІСНИК}

\section{Висновки / Дискусія}

Результати проведеного дослідження підтверджують існуючу думку про те, що дистанційна спеціалізація плавців накладає відбиток на їхній морфотип.

Доведено, що висококваліфіковані спортсмени, які спеціалізуються у плаванні вільним стилем на дистанції 400 метрів, мають: середні значення довжини, маси та обхоплювальних розмірів тіла, довгі кінцівки і їхні сегменти. Їм притаманні переважно сильний тип нервової системи, добре розвинуте почуття часу, висока ступінь концентрації уваги, екстравертований тип особистості, емоційна стійкість.
Виявлено, що серед досліджуваних параметрів структури спеціальної підготовленості плавців високої кваліфікації найбільш впливовими на результат подолання дистанції 400 метрів вільним стилем є показники морфо-функціонального розвитку, в той час як взаємозв'язок психофізіологічних параметрів, за виключенням реакції на звуковий подразник, досить несуттєвий.

Перспектива подальших досліджень полягає у розробці модельних характеристик найбільш значущих параметрів структури спеціальної підготовленості висококваліфікованих спортсменів, які спеціалізуються в плаванні на вільним стилем дистанції 400 метрів.

Конфлікт інтересів. Автори заявляють, що відсутній конфлікт інтересів, який може сприйматись таким, що може завдати шкоди неупередженості статті.

Джерела фінансування. Ця стаття не отримала фінансової підтримки від державної, громадської або комерційної організації.

\section{Список посилань}

1. Булгакова Н. Ж. (1997), Проблема отбора в процессе многолетней подготовки (на материале плавания): автореф. дис. ... д-ра пед. наук. Москва, 65 с.

2. Гречко Т. Н. (1999), Психофизиология: учеб. пособие. Москва, 358 с.

3. Гришин В. А. (2002), Дифференциация тренировочного процесса квалифицированных пловцов в зависимости от специализации: автореф. дис.... канд. пед. наук. Москва, 19 с.

4. Давыдов В. Ю., Авдиенко В. Б. (2012), Отбор и ориентация пловцов по показателям телосложения в системе многолетней подготовки (Теоретические и практические аспекты). Волгоград, 344 с.

5. Ильин Е. П.(2001), Дифференциальная психофизиология. Москва, 235 с.

6. Пилипко О.О., Онопріенко А.О. (2003), «Особливості структури змагальної діяльності висококваліфікованих плавців на дистанції 400 метрів вільним стилем», Физическое воспитание студентов творческих специальностей, № 2, С. 11 - 16.

7. Пилипко О. А. (2013), «Моделирование соревновательной деятельности высококвалифицированных спортсменовпловцов на основе анализа показателей технико-тактического мастерства», Физическое воспитание и спорт в высших учебных заведениях: сборник статей IX международной научной конференции. Белгород, С. 249 - 255.

8. Пилипко О., Пилипко А. (2019), «Взаємозв'язок морфо-функціональних показників зі спортивним результатом у кваліфікованих спортсменів, які спеціалізуються в плаванні вільним стилем на дистанціях різної довжини", Слобожанський науковоспортивний вісник, № 5 (73), С. 82 - 87.

9. Платонов В. Н. (2011), Спортивное плавание: путь к успеху: в 2-х кн, Киев, Кн. 1, 480 с, Кн. 2, 544 с.

10. Филимонова И. Е. (1997), Морфофункциональные особенности пловцов высокого класса и их значение для отбора и дальнейшего спортивного совершенствования: автореф. дис. ...канд. пед. наук. Москва, 25 с.

11. Шинкарук О. А. (2011), Отбор спортсменов и ориентация их подготовки в процессе многолетнего совершенствования (на материале олимпийских видов спорта). Киев, 360 с.

12. Юров И. А. (2006), Психологическое тестирование и психотерапия в спорте. Москва, 164 с.

13. Adams M. (2000), «Thoughts on the crawl stroke», Swimming Technique, №3, pp. 17-24

14. Atkinson John, Sweetenham Bill (2003), Championship swim training, USA : Human Kinetics Publishers, $301 \mathrm{p}$.

15. Pilipko O. (2019), «Features of technical and tactical actions of highly skilled athletes when swimming a distance of 100 meters by front crawl», Slobozhanskyi herald of science and sport, No 2 (70), pp. 31-36.

16. Platonov V., Bulatova M. (1999), «Selection and orientation of athletes in the system of long-term preparation», Sport, Stress, Adaptatio : 1st International Scientific Congress (Sofia, 23-24 October 1999). Sofia, pp. 23.

17. Platonov V. (2006), "General theory of athlete preparation in Olympic sports and methodological aspects of its building-up", European College of Sport Science: book of abstracts of the 11th annual congress of the European College of Sport Science (Lausanne, 5-8 July 2006). Cologne, pp. 531.

Стаття надійшла до редакції: 20.12.2020 р.

Опубліковано: 22.02.2021 p.

Аннотация. Ольга Пилипко, Алина Пилипко. Влияние психофизиологических и морфофункциональных показателей спортсменов высокой квалификации на результат проплывания дистанции 400 метров вольным стилем. Цель: определить влияние психофизиологических и морфофункциональных показателей спортсменов высокой квалификации на результат проплывания ими дистанции 400 метров вольным стилем. Материал и методы: анализ и обобщение литературных источников, антропометрические и физиологические измерения, тестирование психофизиологических показателей, методы математической статистики. Обследуемая группа состояла из участников финальных заплывов Чемпионатов и Кубков Украины по плаванию на дистанции 400 метров вольным стилем, которые имели уровень спортивной квалификации МсУ. Результаты: авторами охарактеризованы психофизиологические и морфофункциональные показатели высококвалифицированных спортсменов, специализирующихся в плавании вольным стилем на дистанции 400 метров, определена степень их влияния на результат преодоления соревновательной дистанции 400 метров. Выводы: показатели морфофункционального развития пловцов являются более значимыми для достижения высоких результатов на дистанции 400 метров вольным стилем, чем психофизиологические параметры; построение тренировочного процесса высококвалифицированных спортсменов различной дистанционной специализации должно осуществляться с учётом степени влияния морфофункциональных и психофизиологических показателей структуры специальной подготовленности на соревновательный результат.

Ключевые слова: высококвалифицированные пловцы, вольный стиль, 400 метров, психофизиологические и морфофункциональные показатели, влияние. 
Abstract. Olga Pilipko, Alina Pilipko. Influence of psychophysiological and morphofunctional indicators of highly qualified athletes on the result of swimming the distance of $\mathbf{4 0 0}$ meters freestyle. Purpose: to determine the influence of psychophysiological and morphofunctional indicators of highly qualified athletes on the result of swimming the distance of 400 meters freestyle. Material and methods: analysis and generalization of literature sources, anthropometric and physiological measurements, testing of psychophysiological indicators, methods of mathematical statistics. The surveyed group consisted of finalists of the Championships and Cups of Ukraine in swimming at the distance of 400 meters freestyle, who had the level of sports qualifications Master of Sports of Ukraine. Results: the authors characterized psychophysiological and morphofunctional indicators of highly qualified athletes who specializing in freestyle swimming at the distance of 400 meters, determined the degree of their influence on the result of overcoming a competitive distance of 400 meters. Conclusions: indicators of morphological and functional development of swimmers are more important for achieving high results at the distance of 400 meters freestyle than psychophysiological parameters; the construction of the training process of highly qualified athletes who have various distance specialization should be carried out taking into account the degree of influence of the morphofunctional and psychophysiological indicators of the structure of special preparedness on the competitive result

Key words: highly qualified swimmers, freestyle, 400 meters, psychophysiological and morphofunctional indicators, influence.

\section{References}

1. Bulhakova, N. Zh. (1997), Problema otbora v protsesse mnoholetnei podhotovky (na materyale plavanyia) [The problem of selection in the process of long-term preparation (based on swimming material)]: avtoref. dis. d-ra ped. Nauk. Moscow, 65 p. (in Russ.)

2. Hrechko, T. N. (1999), Psykhofyzyolohyia [Psychophysiology: a tutorial]: ucheb. posobye. Moscow, 358 p. (in Russ.)

3. Hryshyn, V. A. (2002), Dyfferentsyatsyia trenyrovochnoho protsessa kvalyfytsyrovannukh plovtsov v zavysymosty ot spetsyalyzatsyy [Differentiation of the training process of qualified swimmers depending on the specialization]: avtoref. dys. kand. ped. nauk. Moscow, 19 p. (in Russ.)

4. Davudov, V. Iu., Avdyenko, V. B. (2012), Otbor y oryentatsyia plovtsov po pokazateliam teloslozhenyia v systeme mnoholetnei podhotovky (Teoretycheskye y praktycheskye aspektu) [Selection and orientation of swimmers according to physique indicators in the system of long-term preparation (Theoretical and practical aspects)].Volgograd, 344 p. (in Russ.)

5. Ylyn, E. P.(2001), Dyfferentsyalnaia psykhofyzyolohyia [The differential psychophysiology]. Moscow, 235 p. (in Russ.)

6. Pylypko, O. O., Onoprienko, A. O. (2003), «Features of the structure of competetive activity of highly qualified swimmers at the distance of 400 meters freestyle», Fyzycheskoe vospytanye studentov tvorcheskykh spetsyalnostei, № 2, pp. 11 - 16. (in Ukr.)

7. Pylypko, O. A. (2013), «Modeling of competitive activity of highly qualified sportsmen-swimmers based on the analysis of indicators of technical and tactical skill», Fyzycheskoe vospytanye y sport v vysshykh uchebnykh zavedenyiakh: sbornyk statei IX mezhdunarodnoi nauchnoi konferentsyy. Belgorod, pp. 249 - 255. (in Russ.)

8. Pilipko, O., Pilipko, A. (2019), «Correlation of morphological and functional indicators with sports results among qualified athletes specializing in freestyle swimming at distances of various lengths", Slobozhanskyi herald of science and sport, № 5 (73), pp. 82 - 87. . (in Ukr.)

9. Platonov, V. N. (2012), Sportivnoe plavanie: put k uspekhu [Sports swimming: the path to success]: v 2 kn., Kiev, Knyga1, 480 p., Knyga 2, 544 p. (in Russ.)

10. Fylymonova, Y. E. (1997), Morfofunktsyonalnye osobennosty plovtsov vysokoho klassa y ykh znachenye dlia otbora y dalneisheho sportyvnoho sovershenstvovanyia [Morphofunctional features of high-class swimmers and their importance for selection and further sports improvement]: avtoref. dys. kand. ped. nauk. Moscow, 25 p. (in Russ.)

11. Shinkaruk, O. A. (2011), Otbor sportsmenov y oryentatsyia ykh podhotovky v protsesse mnoholetneho sovershenstvovanyia (na materyale olympyiskykh vydov sporta) [Selection of sportsmen and orientation of their preparation in the process of long-term perfection (on material of Olympic types of sport)]. Kiev, 360 p. (in Russ.)

12. lurov, Y. A. (2006), Psykholohycheskoe testyrovanye y psykhoterapyia v sporte [Psychological testing and psychotherapy in sport]. Moscow, 164 p. (in Russ.)

13. Adams, M. (2000), «Thoughts on the crawl stroke», Swimming Technique, № 3, pp. 17-24. (in Eng.)

14. Pilipko, O. (2019), «Features of technical and tactical actions of highly skilled athletes when swimming a distance of 100 meters by front crawl», Slobozhanskyi herald of science and sport, No 2 (70), pp. 31-36. (in Eng.)

15. Atkinson, John, Sweetenham, Bill (2003), Championship swim training, USA : Human Kinetics Publishers, $301 \mathrm{p}$

16. Platonov, V., Bulatova, M. (1999), "Selection and orientation of athletes in the system of long-term preparation», Sport, Stress, Adaptatio : 1st International Scientific Congress (Sofia, 23-24 October 1999). Sofia, pp. 23. (in Eng.)

17. Platonov, V. (2006), «General theory of athlete preparation in Olympic sports and methodological aspects of its building-up», European College of Sport Science: book of abstracts of the 11th annual congress of the European College of Sport Science (Lausanne, 5-8 July 2006). Cologne, pp. 531. (in Eng.)

Received: 20.12 .2020

Published: 22.02.2021.

\section{Відомості про авторів / Information about the Authors}

Пилипко Ольга Олександрівна: к.пед.н., професор; Харківська державна академія фізичної культури: вул. Клочківська, 99, м. Харків, 61058, Україна.

Пилипко Ольга Александровна: к.пед.н., профессор; Харьковская государственная академия физической культуры: ул. Клочковская, 99, г. Харьков, 61058, Украина

Olga Pilipko: PhD (Pedagogical), Professor; Kharkiv State Academy of Physical Culture: Klochkivska 99, Kharkiv, 61058, Ukraine. ORCID.ORG/0000-0001-8603-3206

E-mail: pilipkoolga@meta.ua

Пилипко Аліна Вікторівна: аспірантка; Харківська державна академія фізичної культури: вул. Клочківська, 99, м. Харків, 61058, Україна.

Пилипко Алина Викторовна: аспирантка; Харьковская государственная академия физической культуры; ул. Клочковская, 99, г. Харьков, 61058, Украина

Alina Pilipko: graduate student; Kharkiv State Academy of Physical Culture: Klochkivska 99, Kharkiv, 61058, Ukraine.

ORCID.ORG/0000-0001-5637-9070

E-mail: alin4ik209@gmail.com 